\title{
Seismic Performance of a Three-Story Reinforced Concrete Building with Masonry Infill Walls and Friction Base Support
}

\author{
Pudjisuryadi, P. ${ }^{* *}$, Prayogo, V.S. ${ }^{2}$, Oetomo, S.I. ${ }^{2}$, and Lumantarna, B. ${ }^{1}$
}

\begin{abstract}
The stiffness of masonry infill walls is commonly neglected in design practice of Reinforced Concrete (RC) structures. In fact, the stiffness of masonry infill wall may significantly influence seismic performance and dynamic behavior of RC buildings. In this research, influence of masonry infill walls to the structural performance of a three-story RC frame is investigated. In addition, possible application of friction-based support is also studied. Full 3D non-linear time history analysis is conducted to observe the behavior of the structure under two-directional ground motion. In the analysis, any failed elements are removed subsequently from the model to avoid numerical analysis problem. The result shows that the masonry infill walls can significantly influence the structural behavior of RC structure. Inappropriate placement of masonry wall may lead the building undergo soft-story mechanism. It is also found that the use of friction-based support can effectively improve the seismic performance of the building.
\end{abstract}

Keywords: Element Removal; Friction Base; Masonry Infill Walls; Non-linear time history analysis; RC Building; Soft Story.

\section{Introduction}

Most Reinforced Concrete (RC) buildings in Indonesia are constructed with unreinforced masonry (URM) infill walls. URM infill walls are generally regarded as non-structural elements which rest on beams. In practice, infill walls are only considered as gravity loads in structural analysis and design. In fact, their stiffnesses may significantly influence structural behavior of RC buildings. Infill wall will interact with reinforced concrete frame as compression strut. Under lateral force, this interaction may contribute as part of resisting system and change the failure mechanism and seismic behavior of the building [1-6].

Many researchers have put efforts to study the influence of infill walls on structure. One approach is to model the URM as continuum model by using finite element analysis [5,7]. Other approach is by replacing the URM with equivalent compression struts. Infill wall model was proposed by FEMA 356 [8] as single equivalent compression strut. This approach based on the assumption that infill walls tend to interact thoroughly with frames on diagonal compressive side and they separate from frame at diagonal tension side [9].

${ }^{1}$ Civil Engineering Department, Petra Christian University, Л. Siwalankerto 121-131, Surabaya 60236, INDONESIA

*Corresponding author; Email: pamuda@petra.ac.id

Note: Discussion is expected before July, $1^{\text {st }} 2021$, and will be published in the "Civil Engineering Dimension", volume 23, number 2, September 2021.

Received 16 July 2020; revised 23 January 2021; accepted 24 january 2021.
However, single equivalent strut is inadequate to model the interaction between infill wall and frame (beam and column), and three equivalent compression struts model was developed and proposed by Kaushik et al. [10].

Pangestu and Polles [11] studied progressive collapse of infill walls in non-engineered residential house. Three equivalent compression struts model was adopted, and 3D non-linear time history analysis was conducted. Failed elements were removed to avoid numerical analysis problem due to local instability of the elements. However, the element removal was done manually, and the analysis was restarted from zero stress state of the modified structure. Santoso and Susanto [12] successfully continued this study with applying element removal in analysis process, without restarting the analysis. However, only one directional earthquake load was applied on the structure.

In this research, influence of masonry infill walls to the structural performance of a three-story RC frame is investigated, considering in plane (IP) and out of plane (OOP) behavior of the infill wall. In addition, possible application of friction-based support is also modeled and studied. Element removal feature in SAP2000 v21.2 [13] is employed to remove failed element to avoid local instability. The seismic load is simultaneously applied to the structure in both orthogonal directions.

\section{In-Plane (IP) Properties of URM infill wall}

The masonry infill walls are modeled by using equivalent single strut model proposed by FEMA 356 [8]. Actual thickness of URM infill wall $\left(t_{i n f}\right)$ is used in 
the model, while equivalent strut width $\left(w_{s}\right)$ is determined by using Equations 1 to 3 , where $r_{\text {inf }}$ is the diagonal length of the infill wall; $\lambda_{\mathrm{h}}$, a coefficient (defined in Equation 2); hinf, the height of infill wall; $E_{\text {inf }}$, the modulus of elasticity of infill wall; $f_{m}^{\prime}$, the compressive strength of infill wall; $\theta$, the slope of diagonal strut; $\mathrm{E}_{\mathrm{c}}$, the modulus of elasticity of concrete frame; and $\mathrm{I}_{\mathrm{col}}$, the second moment of inertia of column.

$w_{s}=0.175 \times r_{i n f} \times\left(\lambda_{h} \times h_{\text {inf }}\right)^{-0.4}$

$\lambda_{h}=\left[\frac{E_{\text {inf }} \times t_{\text {inf }} \times \sin 2 \theta}{4 \times E_{c} \times I_{\text {col }} \times h_{\text {inf }}}\right]^{1 / 4}$

$E_{\text {inf }}=550 \times f_{m}^{\prime}$

The IP axial capacity of the equivalent strut $\left(\mathrm{P}_{\mathrm{n}}\right)$ is calculated by using shear and compressive strengths of the infill wall. The capacity is given by the minimum value of Equations 4 and 5 as follows:

$\mathrm{P}_{\mathrm{n}}=\mathrm{V}_{\text {ine }} / \cos \theta$

$\mathrm{P}_{\mathrm{n}}=\mathrm{f}_{\mathrm{m}}^{\prime} \times \mathrm{A}_{\mathrm{s}}$

where $V_{\text {ine }}$ is the shear strength of infill wall and $A_{s}$, the cross sectional area of equivalent diagonal strut.

\section{Out-of-Plane (OOP) Properties of URM Infill Wall}

The OOP capacity of the strut model is expressed by using an equivalent flexural capacity $\left(\mathrm{M}_{\mathrm{y}_{-} \mathrm{eq}}\right)$ as proposed by Kadysiewski and Mosalam [14]. Expressions to determine the capacity is given in Equations 6 to 8 as follows:

$\mathrm{M}_{\mathrm{y}_{-} \text {eq }}=1.570 \times \frac{\mathrm{L}_{\text {diag }}}{\mathrm{h}_{\mathrm{inf}}} \times \mathrm{M}_{\text {yinf }}$

$\mathrm{M}_{\text {yinf }}=1 / 8 \times \mathrm{q}_{\mathrm{in}} \times \mathrm{h}_{\mathrm{inf}}{ }^{2} \times \mathrm{L}_{\mathrm{inf}}$

$\mathrm{q}_{\text {in }}=\frac{0.7 \times{f^{\prime}}_{m} \times \lambda_{2}}{\frac{h_{\text {inf }}}{t_{\text {inf }}}}$

where $\mathrm{L}_{\text {diag }}=\mathrm{rinf}_{\text {is }}$ the diagonal length of infill wall;

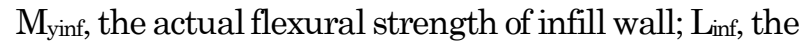
horizontal length of infill wall; and $\lambda_{2}$, slenderness parameter as defined in Tables 7-11 of FEMA 356 [8]. In this model, the dynamic behavior of the infill wall is assumed to be dominantly governed by the first mode. To obtain similar dynamic behavior, the natural frequency of the equivalent diagonal strut is set the same as the actual infill wall [14], which requires lumped equivalent modal effective mass (MEM) at midpoint of the diagonal strut as seen in Figure 1. This equivalent modal effective mass for the first mode is equal to $81 \%$ of actual mass of the infill wall $\left(\mathrm{M}_{\mathrm{inf}}\right)$, which is the MEM of the first mode.

In order to get natural frequency that is equal to that of the actual infill wall, a modification of second moment of inertia ( $\mathrm{I}_{\text {eqinf }}$ ) is necessary, which can be calculated by using Equations 10 to 12 proposed by Kadysiewski and Mosalam [14] as follows:

$I_{\text {eqinf }}=\frac{k_{e q} \times L_{\text {diag }}{ }^{3}}{48 \times E_{\text {inf }}}$

$k_{e q}=\left(2 \times \pi \times f_{s s}\right)^{2} \times M E M$

$f_{S S}=\frac{\pi \times \sqrt{\frac{E_{\text {inf }} \times I_{\text {inf }} w_{\text {inf }}}{w_{\text {inck }} \times g}}}{2 \times h_{\text {inf }}{ }^{2}}$

where $\mathrm{k}_{\mathrm{eq}}=$ the equivalent OOP stiffness which provide the identical frequency; $\mathrm{f}_{\mathrm{ss}}=$ the first mode natural frequency of actual infill wall, and $\mathrm{I}_{\text {inf crack }}=$ the cracked second moment of inertia of infill wall which is taken as $50 \%$ of its gross second moment of inertia.

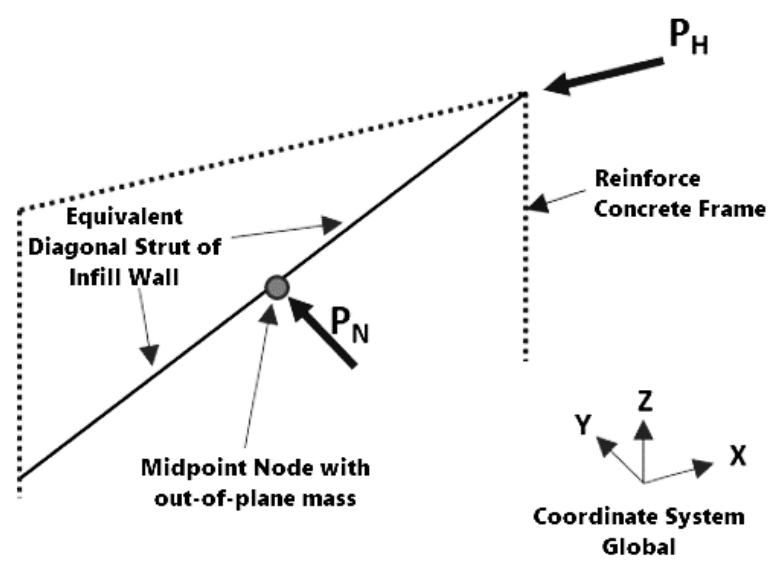

Figure 1. OOP Model of the Equivalent Single Diagonal Strut.

\section{Interaction of IP and OOP Capacity of URM Infill Wall}

Kadysiewski and Mosalam [14] proposed the interaction between IP and OOP capacity of infill wall as expressed in Equation 13.

$\left(\frac{P_{n}}{P_{n o}}\right)^{\frac{3}{2}}+\left(\frac{P_{h}}{P_{h o}}\right)^{\frac{3}{2}} \leq 1.0$

where $\mathrm{P}_{n}$ is the OOP capacity in the presence of IP force, $\mathrm{P}_{\text {no }}$ is the OOP capacity without presence of IP force, $\mathrm{P}_{\mathrm{h}}$ is the IP capacity with presence of OOP force, $\mathrm{P}_{\text {ho }}$ is the IP capacity without presence of OOP force.

\section{Friction Base Isolation}

Possible application of friction-based support is simulated in this study to investigate its potential in dissipating earthquake energy. The support is not anchored to the foundation but is assumed to have certain friction coefficient. The friction capacity of the support is the product of the friction coefficient and normal force perpendicular to the plane of friction. During time history analysis, the friction-based supports remain stationary if the horizontal reaction force is less than the friction capacity. Otherwise, it moves horizontally and stops again after the horizontal force drops below the friction capacity. 


\section{Building and Loads Considered}

Two by three bay, three-story reinforced concrete building as seen in Figure 2 was modeled and designed. This considered building was designed by using current Indonesian Concrete and Seismic codes $[15,16]$. Building plan view is shown in Figure 3. The important data of this building is summarized in Table 1.

Table 1. Parameter Properties of 3-Story RC Building

\begin{tabular}{lll}
\hline Parameter & 'emark \\
\hline$>$ & Dimension of building & $0 \times 15 \mathrm{~mm}^{2}$ \\
$>$ & Number of bay, X & \\
$>$ & Number of bay, Y & \\
$>$ & Bay width, X and Y & $\mathrm{m}$ \\
$>$ & Number of stories & \\
$>$ & Story height & $\mathrm{m}$ \\
$>$ & Concrete compressive strength $5 \mathrm{MPa}$ \\
& $\left(\mathrm{f}_{\mathrm{c}}^{\prime}\right)$ & \\
$>$ & Yield strength of steel bar $\left(\mathrm{f}_{\mathrm{y}}\right)$ & $\mathrm{iJ} 55 ; \mathrm{f}_{\mathrm{y}}=400 \mathrm{MPa}$ \\
$>$ & Beam & $50 \times 400 \mathrm{~mm}^{2}$ \\
$>$ & Column & $50 \times 350 \mathrm{~mm}^{2}$ \\
$>$ & Slab thickness & $25 \mathrm{~mm}$ \\
$>$ & Infill wall thickness & $50 \mathrm{~mm}$ \\
$>$ & Type of foundation & ile $(\mathrm{Fixed})$ \\
$>$ & Live load & $50 \mathrm{~kg} / \mathrm{m}^{2}$ \\
$>$ & Additional dead load & $50 \mathrm{~kg} / \mathrm{m}^{2}$ \\
$>$ & Live load at rooftop & $00 \mathrm{~kg} / \mathrm{m}^{2}$ \\
$>$ & Dead load at rooftop & $0 \mathrm{~kg} / \mathrm{m}^{2}$ \\
\hline
\end{tabular}

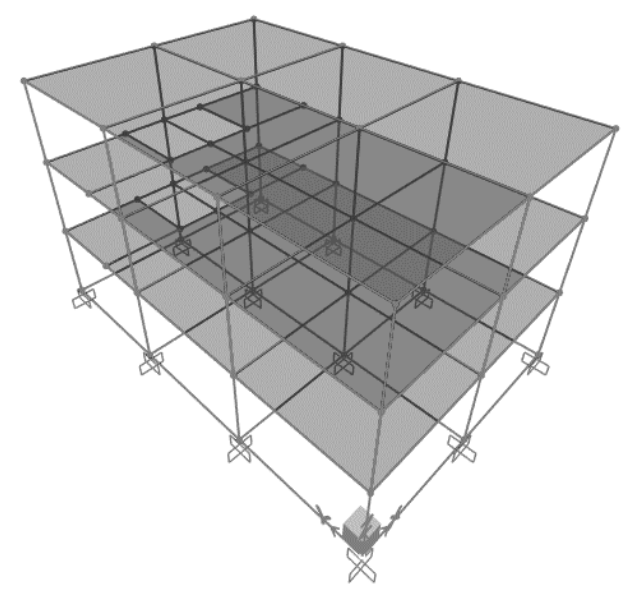

Figure 2. The 3D Illustration of Considered Reinforced Concrete Building

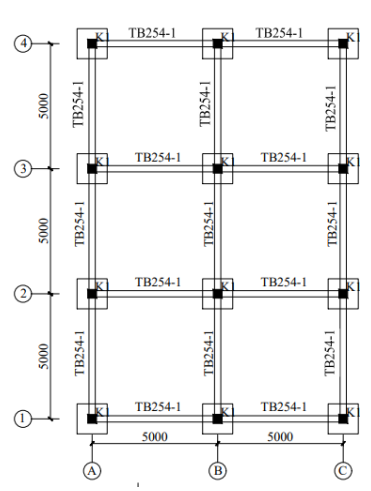

(a)

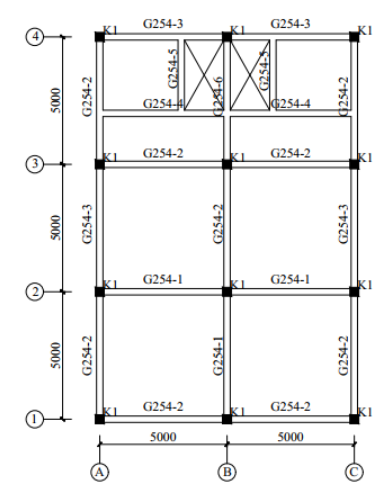

(b)

In this building, URM infill walls are located in all stories except the bottom story. It is intended to represent typical commercial building with more open area at bottom story. Modeling techniques and assumptions of infill wall are adopted from Kaushik, Rai, \& Jain [10].

In this study, infill wall is modeled as double three equivalent diagonal struts as seen in Figure 4(a) and 5(a). Some parameters based on single equivalent diagonal strut are modified as necessary. The width of single strut is divided into $50 \%$ and $2 \times 25 \%$ for the middle strut and two side struts respectively, to model three equivalent struts. The modal effective mass (MEM) is divided into lump mass on each mid-point of the double three equivalent diagonal struts. One fourth (25\%) of MEM and one eight (12.5\%) of MEM are assigned as lump masses for middle struts and side struts, respectively. Due to the different lump mass and length of each strut, the second moment of inertia in OOP direction should be adjusted to be equal as the natural frequency of the actual infill wall. Thereafter, IP and OOP capacities are adjusted based on proportion of MEM of each strut.

Further, IP mass is lumped at each corner of RC frame concrete and modeled with additional mass on dummy frame. Gravity load of infill wall is assigned to beam also by using rigid dummy frames. This rigid dummy frames (no self-mass and stiffness) are removed if the infill wall in that panel fails.

There are four variation of building model analyzed in this study, i.e. Fixed Base-Infill Wall (FIX-INF), Fixed Base-Load (FIX-LOAD), Friction Base-Infill Wall (FRB-INF), Friction Base-LOAD (FRB-LOAD). FIX and FRB indicate the assumption of fixed and frictionbased supports, respectively. INF indicate that infill wall is considered as structural elements, while LOAD assumed the infill wall as mass and load without any stiffness contribution to the building. The assumption variations of the building can be seen in Figure 4 and Figure 5.

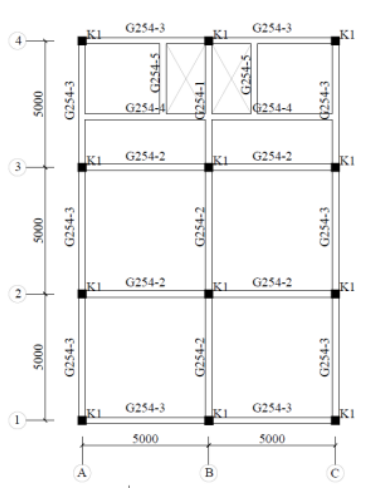

(c)

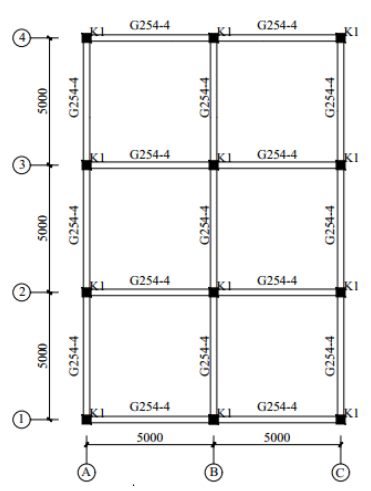

(d)

Figure 3. Building Plan: (a) First Story; (b) Second Story; (c) Third Story; (d) Rooftop 


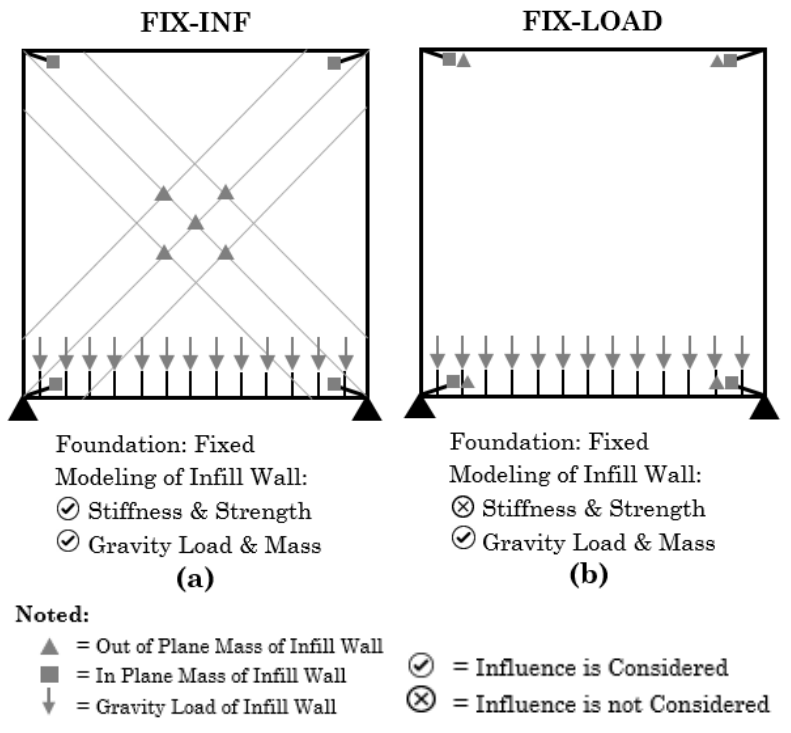

Figure 4. Variation Model Based on Fixed Foundation

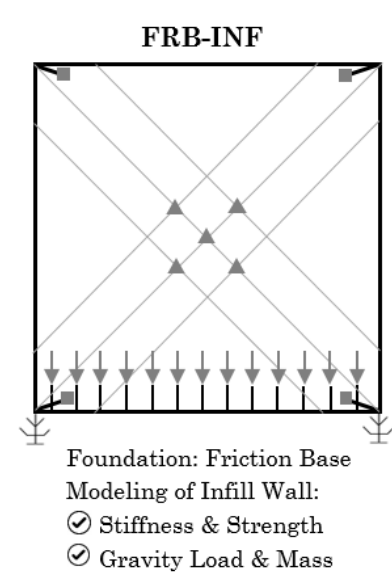

(c)

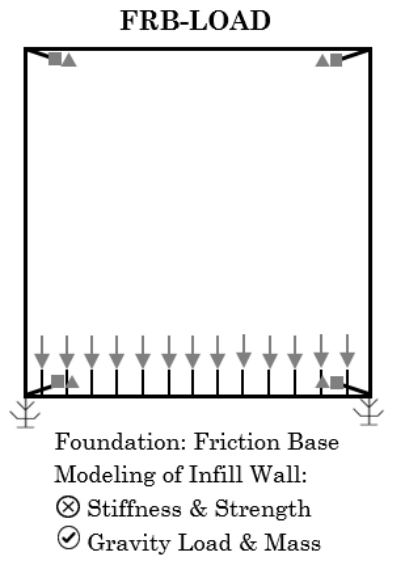

(d)
Noted:

$$
\begin{aligned}
\mathbf{\Delta} & =\text { Out of Plane Mass of Infill Wall } \\
& =\text { In Plane Mass of Infill Wall } \\
\downarrow & =\text { Gravity Load of Infill Wall }
\end{aligned}
$$

$($ = Influence is Considered

$\otimes=$ Influence is not Considered

Centro 1940 accelerogram NS and EW component can be seen in Figure 6. The structures are subjected to this two-directional modified ground motions twice, where NS component acts in X-direction (scheme 1) and in Y-direction (scheme 2). Element removal feature is used once any element (rc frame or URM infill wall) failure is detected.

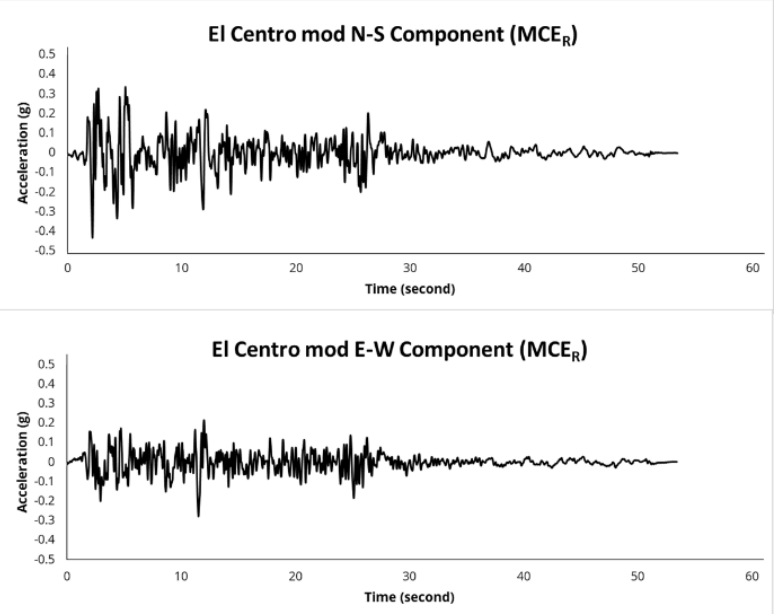

Figure 6. Modified El Centro 1940 (El Centro Mod) Accelerogram N-S and E-W Direction

\section{Seismic Performance}

Seismic performance of the structure is determined based on severity of plastic hinge damage, maximum drift ratio, and maximum base shear. Table 2 shows plastic hinge damage level of the three-story RC Building. Damage index value is obtained by averaging the damage level of plastic hinges in structure. The state A-B shows that element still does not experience any plastic damages, and point $\mathrm{B}$ shows the initial yielding of $\mathrm{RC}$ element. Points IO, $\mathrm{LS}$, and CP indicate that the element experiences $10 \%, 25 \%$, and $40 \%$ of its ultimate deformation. While point $\mathrm{E}$ marks the ultimate deformation of the element. It can be observed that damage indices of RC frames in all building models are at B-IO level, which indicates that building can be used after earthquake. Damage index of buildings due to earthquake scheme 1 is greater than earthquake scheme 2 since dominant earthquake acts on the weak axes of the structure.

Stiffness and strength of URM infill wall give significant influence on the building's seismic performances. Table 3 shows maximum drift ratio and maximum base shear in both axis of the building. In both earthquake schemes at both earthquake levels (design earthquake and $\mathrm{MCE}_{\mathrm{R}}$ ), FIX-INF model has the largest maximum drift ratio in both directions. This condition indicates that presence of stiffness and strength of infill wall using a fixed foundation can decrease the seismic performance of the building. The 
decreased performance is caused by soft-story mechanism of first story which has lower stiffness than second and third stories. Meanwhile, FRB-INF models has the smallest maximum drift ratio in both directions. Stiffness and strength of infill wall can increase the seismic performance of building when friction base foundation dissipate enough earthquake energy to prevent excessive damages.

Table 2. Plastic Hinge Damage Level of Three-Story RC Building

\begin{tabular}{|c|c|c|c|c|c|c|c|c|c|c|}
\hline Building Model & $\begin{array}{r}\mathbf{A}-\mathbf{B} \\
0 \% \\
\end{array}$ & $\begin{array}{c}\text { B-IO } \\
(0-10 \%)\end{array}$ & $\begin{array}{c}\text { IO-LS } \\
(10-25 \%)\end{array}$ & $\begin{array}{c}\text { LS-CP } \\
(25-40 \%)\end{array}$ & $\begin{array}{c}\text { CP-E } \\
(40-100 \%)\end{array}$ & $\begin{array}{c}>\mathbf{E} \\
(>100 \%)\end{array}$ & Total & $\begin{array}{l}\text { Plastic } \\
\text { Hinge }\end{array}$ & $\begin{array}{c}\text { Damage } \\
\text { Index }\end{array}$ & $\begin{array}{c}\text { Performance } \\
\text { Level }\end{array}$ \\
\hline \multicolumn{11}{|c|}{ Scheme 1: X Dominant Earthquake } \\
\hline \multicolumn{11}{|c|}{ Design Earthquake } \\
\hline FIX-INF & 130 & 85 & 9 & 0 & 0 & 0 & 224 & $42.00 \%$ & $6.20 \%$ & B-IO \\
\hline FIX-LOAD & 106 & 108 & 10 & 0 & 0 & 0 & 224 & $52.70 \%$ & $6.06 \%$ & B-IO \\
\hline FRB-LOAD & 119 & 105 & 0 & 0 & 0 & 0 & 224 & $46.90 \%$ & $5.00 \%$ & B-IO \\
\hline FRB-INF & 190 & 34 & 0 & 0 & 0 & 0 & 224 & $15.20 \%$ & $5.00 \%$ & B-IO \\
\hline \multicolumn{11}{|l|}{$\mathrm{MCE}_{\mathrm{R}}$ Earthquake } \\
\hline FIX-INF & 117 & 71 & 36 & 0 & 0 & 0 & 224 & $47.80 \%$ & $9.21 \%$ & B-IO \\
\hline FIX-LOAD & 92 & 118 & 14 & 0 & 0 & 0 & 224 & $58.90 \%$ & $6.33 \%$ & B-IO \\
\hline FRB-LOAD & 92 & 130 & 2 & 0 & 0 & 0 & 224 & $58.90 \%$ & $5.19 \%$ & B-IO \\
\hline FRB-INF & 178 & 46 & 0 & 0 & 0 & 0 & 224 & $20.50 \%$ & $5.00 \%$ & B-IO \\
\hline \multicolumn{11}{|c|}{ Scheme 2: Y Dominant Earthquake } \\
\hline \multicolumn{11}{|c|}{ Design Earthquake } \\
\hline FIX-INF & 150 & 67 & 7 & 0 & 0 & 0 & 224 & $33.00 \%$ & $6.18 \%$ & B-IO \\
\hline FIX-LOAD & 112 & 104 & 8 & 0 & 0 & 0 & 224 & $50.00 \%$ & $5.89 \%$ & B-IO \\
\hline FRB-LOAD & 126 & 98 & 0 & 0 & 0 & 0 & 224 & $43.80 \%$ & $5.00 \%$ & B-IO \\
\hline FRB-INF & 192 & 32 & 0 & 0 & 0 & 0 & 224 & $14.30 \%$ & $5.00 \%$ & B-IO \\
\hline \multicolumn{11}{|l|}{$\mathrm{MCE}_{\mathrm{R}}$ Earthquake } \\
\hline FIX-INF & 130 & 63 & 31 & 0 & 0 & 0 & 224 & $42.00 \%$ & $9.12 \%$ & B-IO \\
\hline FIX-LOAD & 82 & 127 & 15 & 0 & 0 & 0 & 224 & $63.40 \%$ & $6.32 \%$ & B-IO \\
\hline FRB-LOAD & 93 & 129 & 2 & 0 & 0 & 0 & 224 & $58.50 \%$ & $5.19 \%$ & B-IO \\
\hline FRB-INF & 165 & 59 & 0 & 0 & 0 & 0 & 224 & $26.30 \%$ & $5.00 \%$ & B-IO \\
\hline
\end{tabular}

Table 3. Maximum Drift Ratio and Maximum Base Shear of Three-Story RC Building

\begin{tabular}{|c|c|c|c|c|c|c|}
\hline Building Model & $\begin{array}{c}\text { Max Story Drift } \\
\text { X-Dir (mm) }\end{array}$ & $\begin{array}{c}\text { Max Story Drift } \\
\text { Y-Dir (mm) }\end{array}$ & $\begin{array}{l}\text { Drift Ratio X- } \\
\text { Dir (\%) }\end{array}$ & $\begin{array}{l}\text { Drift Ratio } \\
\text { Y-Dir (\%) }\end{array}$ & $\begin{array}{c}\text { Max Base Shear } \\
\text { X-Dir (kN) }\end{array}$ & $\begin{array}{c}\text { Max Base Shear } \\
\text { Y-Dir (kN) }\end{array}$ \\
\hline \multicolumn{7}{|c|}{ Scheme 1: X Dominant Earthquake } \\
\hline \multicolumn{7}{|c|}{ Design Earthquake } \\
\hline FIX-INF & 72.58 & 45.72 & $2.42 \%$ & $1.52 \%$ & 1460.77 & 1206.98 \\
\hline FIX-LOAD & 67.95 & 31.13 & $2.27 \%$ & $1.04 \%$ & 1201.38 & 1030.59 \\
\hline FRB-LOAD & 42.28 & 30.94 & $1.41 \%$ & $1.03 \%$ & 955.02 & 955.40 \\
\hline FRB-INF & 27.38 & 17.55 & $0.91 \%$ & $0.59 \%$ & 968.93 & 925.10 \\
\hline \multicolumn{7}{|l|}{$\mathrm{MCE}_{\mathrm{R}}$ Earthquake } \\
\hline FIX-INF & 83.59 & 51.05 & $2.79 \%$ & $1.70 \%$ & 1394.92 & 1193.47 \\
\hline FIX-LOAD & 70.78 & 50.71 & $2.36 \%$ & $1.69 \%$ & 1274.24 & 1030.59 \\
\hline FRB-LOAD & 48.90 & 38.82 & $1.63 \%$ & $1.29 \%$ & 951.40 & 952.57 \\
\hline FRB-INF & 41.17 & 25.80 & $1.37 \%$ & $0.86 \%$ & 960.43 & 954.69 \\
\hline \multicolumn{7}{|c|}{ Scheme 2: Y Dominant Earthquake } \\
\hline \multicolumn{7}{|c|}{ Design Earthquake } \\
\hline FIX-INF & 40.98 & 56.98 & $1.37 \%$ & $1.90 \%$ & 1157.78 & 1439.46 \\
\hline FIX-LOAD & 27.05 & 47.59 & $0.90 \%$ & $1.59 \%$ & 992.67 & 1198.68 \\
\hline FRB-LOAD & 26.29 & 36.62 & $0.88 \%$ & $1.22 \%$ & 849.63 & 966.16 \\
\hline FRB-INF & 20.11 & 22.53 & $0.67 \%$ & $0.75 \%$ & 921.44 & 965.25 \\
\hline \multicolumn{7}{|l|}{$\mathrm{MCE}_{\mathrm{R}}$ Earthquake } \\
\hline FIX-INF & 58.77 & 80.37 & $1.96 \%$ & $2.68 \%$ & 1125.95 & 1387.42 \\
\hline FIX-LOAD & 47.85 & 65.12 & $1.59 \%$ & $2.17 \%$ & 1053.66 & 1384.97 \\
\hline FRB-LOAD & 43.64 & 44.13 & $1.45 \%$ & $1.47 \%$ & 913.44 & 950.35 \\
\hline FRB-INF & 36.28 & 38.77 & $1.21 \%$ & $1.29 \%$ & 937.42 & 963.26 \\
\hline
\end{tabular}


The damages of the three-story $\mathrm{RC}$ building in each model can be seen in Figures 7 to 10. The damage of infill wall can be observed by the hinge color. Dark blue color on the infill wall indicates that load received by infill wall is $50 \%$ of its capacity. Light blue color indicates that load received by infill wall is $80 \%$ of its capacity. If the stress resultants exceed the capacity, the infill wall will be removed by using element removal feature.
In term of base shear, it can be observed that building models with fixed supports (FIX-INF and FIX-LOAD) have larger maximum base shears than that of friction-based support models (FRB-INF and FRBLOAD) in both directions. It is obvious that frictionbased supports are very beneficial to the seismic performance that it can effectively dissipate seismic energy of the three-story RC building.

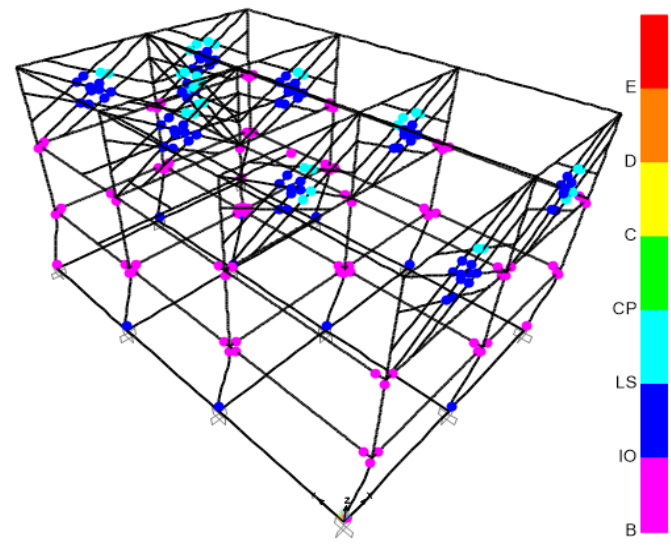

(a)

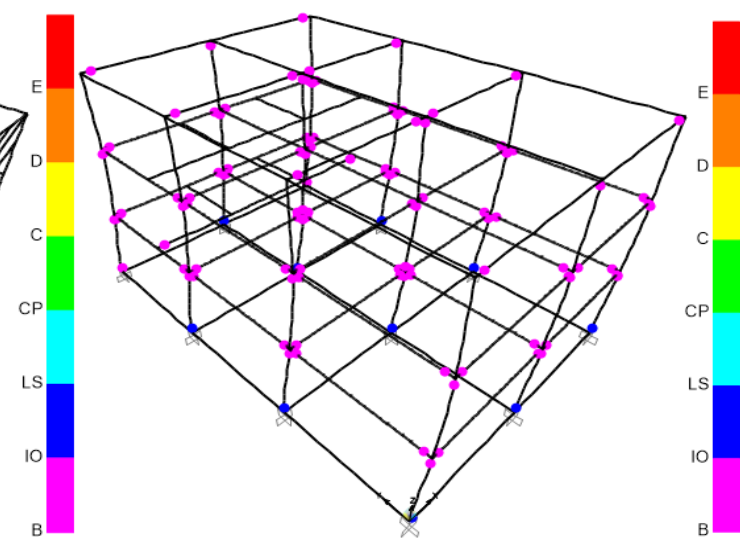

(b)

Figure 7. Damages of Three-Story RC Building in Final Step t=50s for Scheme 1 Design Earthquake Level: (a) FIX-INF, (b) FIX-LOAD

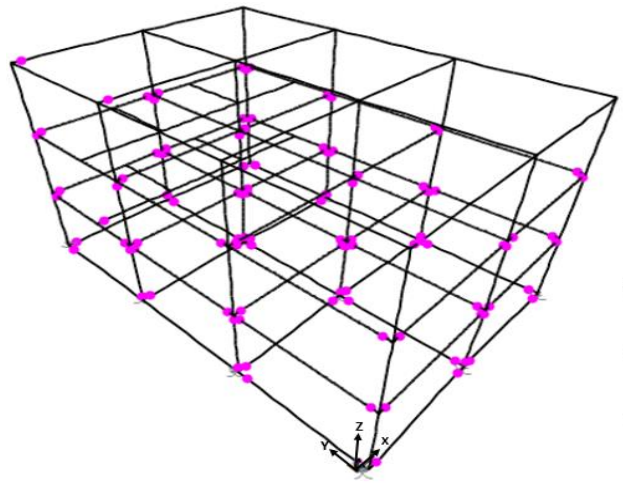

(a)
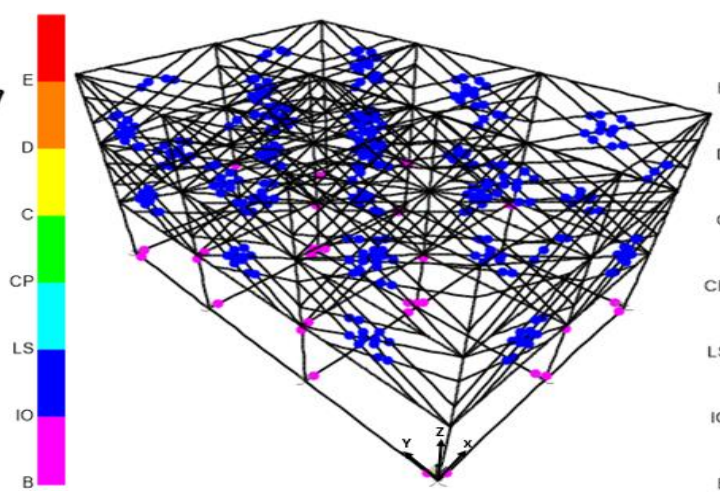

(b)

Figure 8. Damages of Three-Story RC Building in Final Step t=50s for Scheme 1 Design Earthquake Level: (a) FRBLOAD, (b) FRB-INF

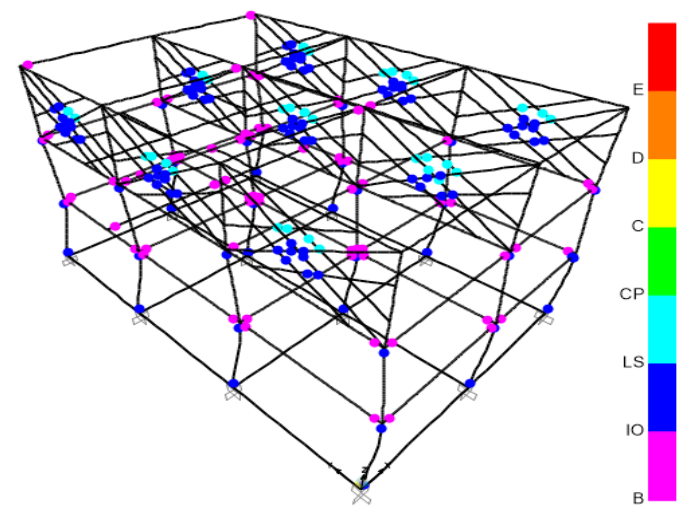

(a)

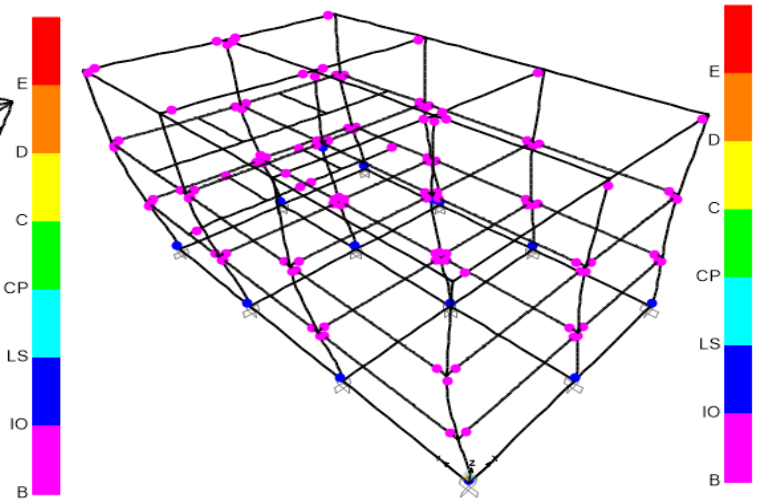

(b)

Figure 9. Damages of Three-Story RC Building in Final Step t=50s for Scheme 1 MCER Earthquake: (a) FIX-INF, (b) FIXLOAD 


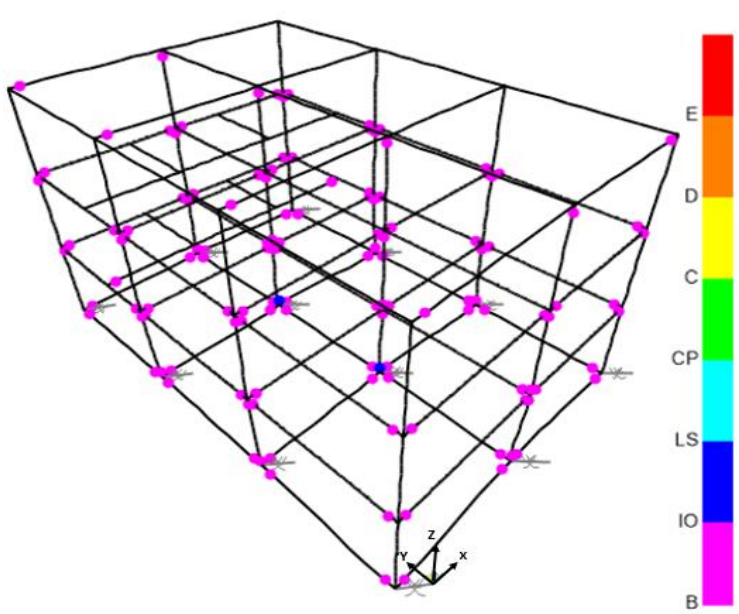

(a)

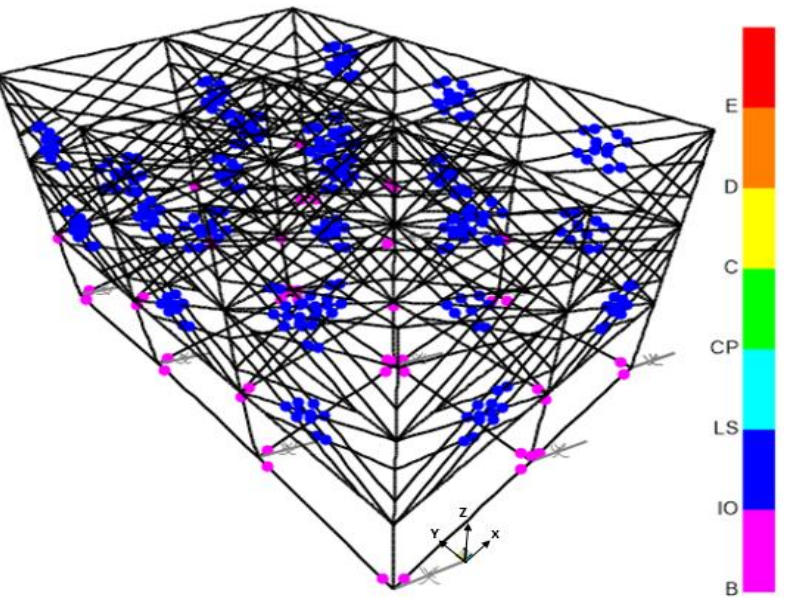

(b)

Figure 10. Damages of Three-Story RC Building in Final Step t=50s for Scheme 1 MCER Earthquake: (a) FRB-LOAD, (b) FRB-INF

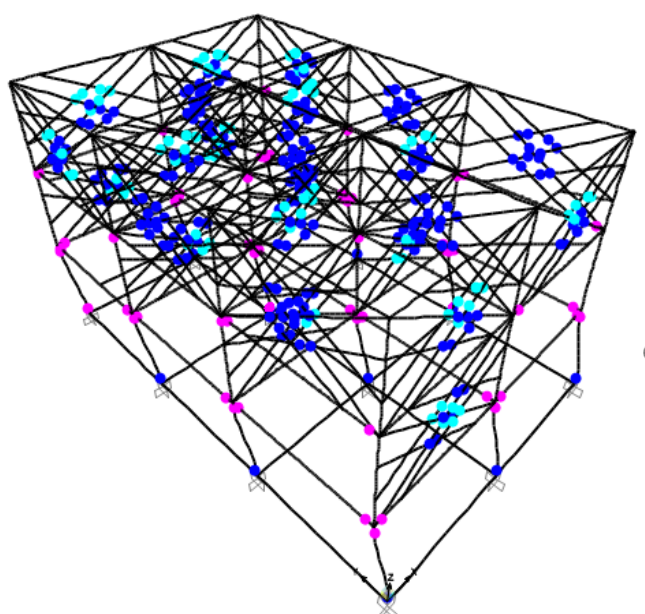

(a)
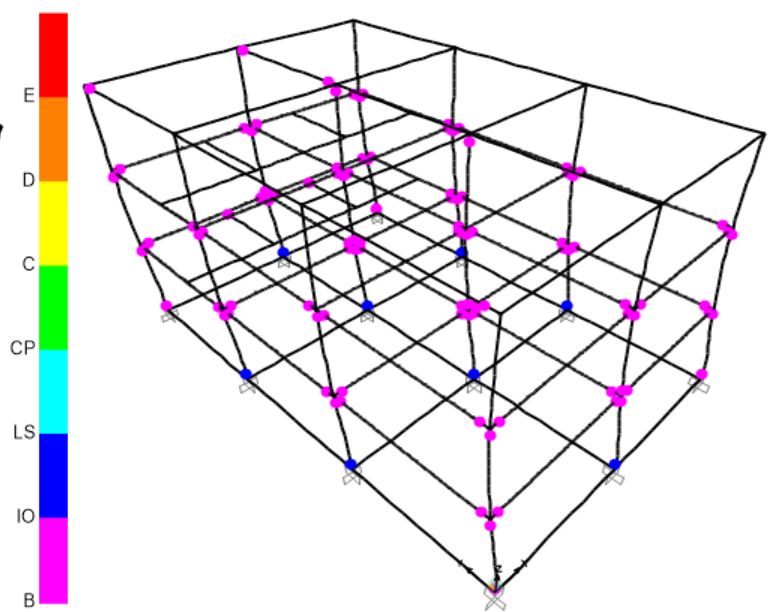

(b)

Figure 11. Damages of Three-Story RC Building in Final Step t=50s for Scheme 2 Design Earthquake Level: (a) FIX-INF, (b) FIX-LOAD

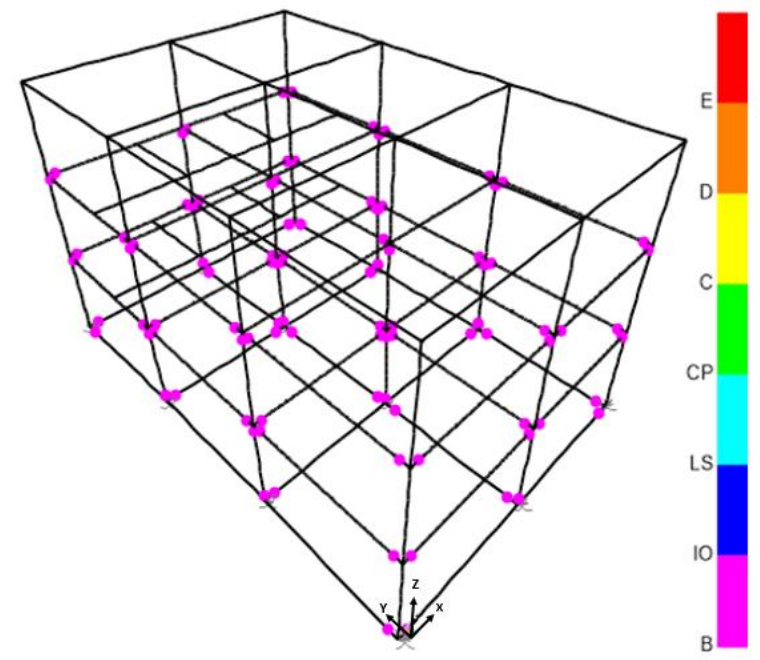

(a)

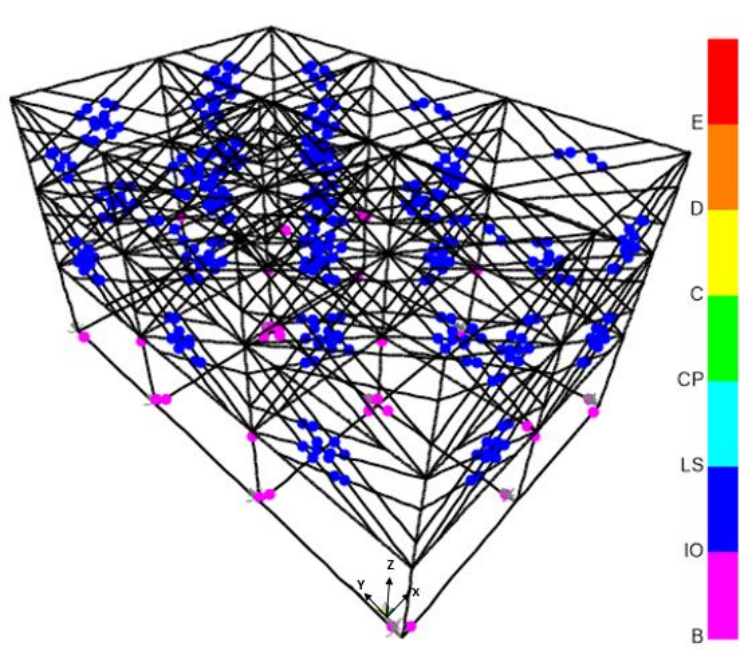

(b)

Figure 12. Damages of Three-Story RC Building in Final Step t=50s for Scheme 2 Design Earthquake Level: (a) FRBLOAD, (b) FRB-INF 


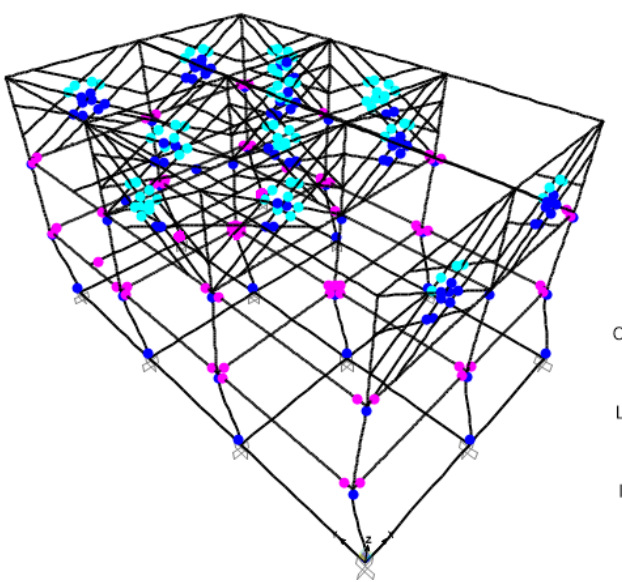

(a)

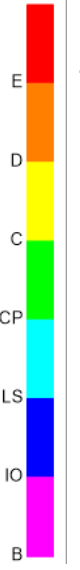

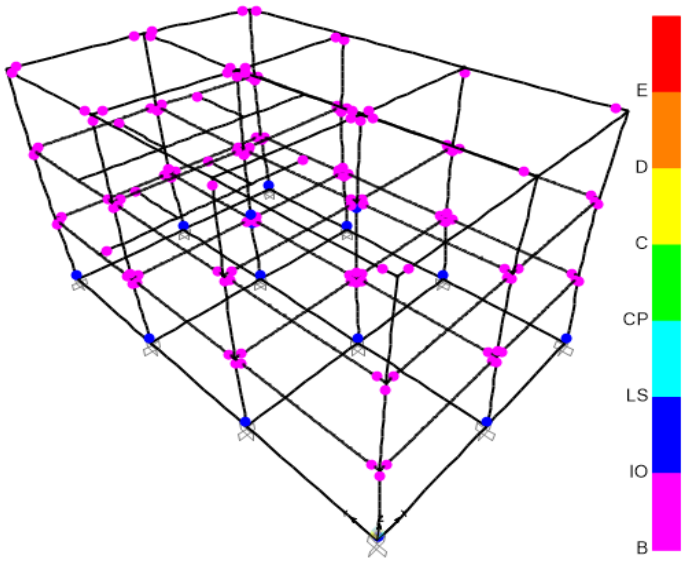

(b)

Figure 13. Damages of Three-Story RC Building in Final Step t=50s for Scheme 2 MCER Earthquake: (a) FIX-INF, (b) FIXLOAD

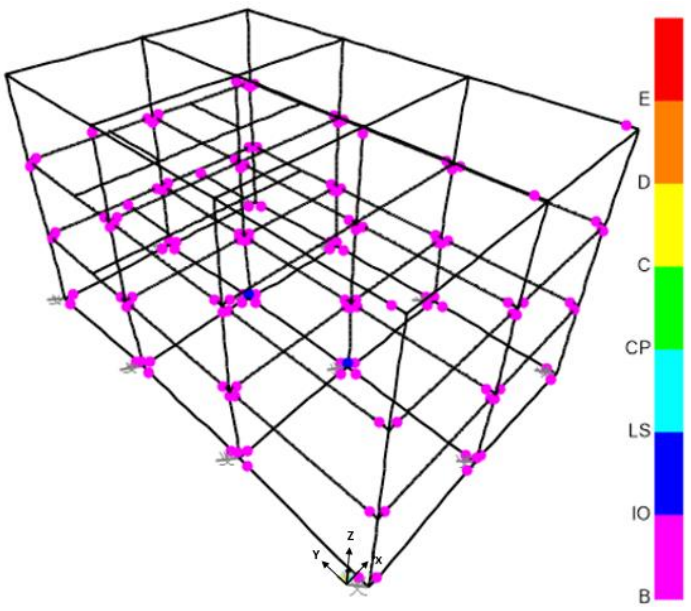

(a)

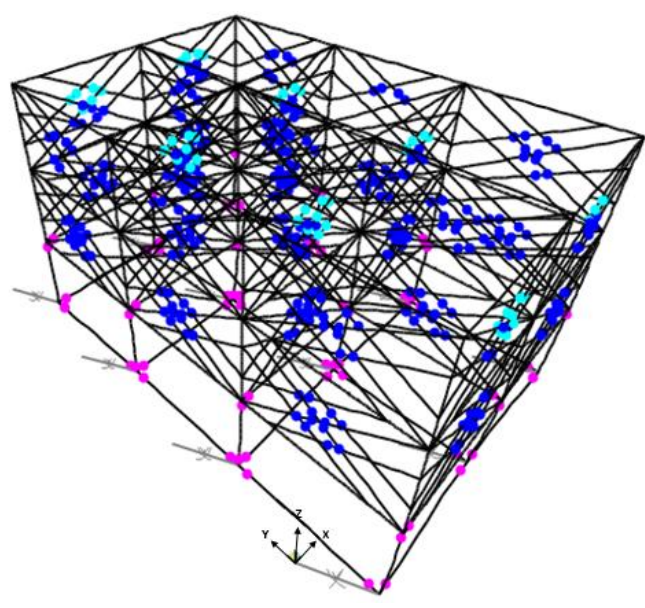

(b)

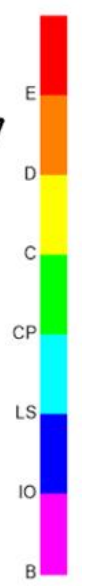

Figure 14. Damages of Three-Story RC Building in Final Step $t=50$ s for Scheme 2 MCER Earthquake: (a) FRB-LOAD, (b) FRB-INF

\section{Conclusions}

The influence of URM infill wall and friction-based supports to the structural performance of the building is investigated in this study. From the analysis results, some conclusions can be summarized. URM infill walls can significantly change the dynamic behavior of RC structure. In models with fix supports, the interstory drift of the buildings with URM considered as structural elements are larger. For example, for structures subjected to design earthquake with Scheme 1, the interstory drift increases from $67.95 \mathrm{~mm}$ to $72.58 \mathrm{~mm}$. This is caused by more severe soft-story mechanism at the first story resulting from URM infill walls which are located only on the second and third story of the building. However, if friction-based supports are applied, reversed seismic performances of the buildings are observed. In this case, the interstory drift of the buildings with URM considered as structural element are smaller. Due to design earthquake with Scheme
1, the interstory drift decreases from $42.28 \mathrm{~mm}$ to $27.38 \mathrm{~mm}$. When the inertia force is reduced small enough that it does not severely damage the first story, the effect of stiffness irregularity is less significant, and the relatively stiffer second and third stories may reduce the overall building drift. These facts are also true for analysis at any combination of earthquake levels (design or maximum considered earthquakes), and their directions (Schemes 1 or 2).

\section{References}

1. Lima, C., De Stefano, G., and Martinelli E., Seismic Response of Masonry Infilled RC Frames: Practice-oriented Models and Open Issues, Earthquakes and Structures, 6(4), 2014, pp 409436. https://doi.org/10.12989/EAS.2014.6.4.409.

2. Sönmez, E., Effect of Infill Wall Stiffness Variations on the Behavior of Reinforced Concrete Frames under Earthquake Demands, 2013, retrieved 1 December 2020, from http:/hdl.handle.net/11147/3567. 
3. Benavent-Climent, A., Ramírez-Márquez, A., and Pujol, S., Seismic Strengthening of Low-rise Reinforced Concrete Frame Structures with Masonry Infill Walls: Shaking-table Test, Engineering Structures, 165, 2018, pp.142-151. doi: 10.1016/j. engstruct.2018.03.026.

4. Griffith, M., Seismic Retrofit of RC Frame Buildings with Masonry Infill Walls: Literature Review and Preliminary Case Study, European Commission Joint Research Centre Institute for the Protection and Security of the Citizen, Italy, 2008.

5. Azzi, Z., Behavior of Un-reinforced Concrete Masonry Infill Walls under Lateral Earthquake Loads, 2017, doi: 10.26756/th.2017.7.

6. Abdelkareem, K. H., Sayed, F. K. A., Ahmed, M. H., and AL-Mekhlafy, N., Equivalent Strut Width for Modeling R.C. Infilled Frames, Journal of Engineering Sciences, 41(3), 2013, pp. 851-866, retrieved from http://www.aun.edu. eg/journal_ files/140_J_1640.pdf.

7. Koutromanos, I., Stavridis, A., Shing, P., and Willam, K., Numerical Modeling of MasonryInfilled RC Frames Subjected to Seismic Loads, Computers \& Structures, 89(11-12), 2011, pp. 1026-1037, doi: 10.1016/j.compstruc.2011.01.006

8. FEMA 356-2000, Pre-standard and Commentary for the Seismic Rehabilitation of Buildings, American Society of Engineers, 2000.

9. Mosalam, K. and Günay, S., Progressive Collapse Analysis of Reinforced Concrete Frames with Unreinforced Masonry Infill Walls considering In-Plane/Out-of-Plane Interaction, Earthquake Spectra, 31(2), 2015, pp. 921-943.
10. Kaushik, H. B., Rai, D. C., and Jain, S. K., A Rational Approach to Analytical Modeling of Masonry Infills in Reinforced Concrete Frame Buildings, The 14th World Conference on Earthquake Engineering, Indian Institute of Technology, Beijing, China, October 12-17, 2008.

11. Pangestu, S. A. and Polles, L. J., Efek Element Removal Terhadap Kinerja Seismic Rumah Sederhana dengan Dinding Bata Pengisi, Undergraduate Theses, Civil Engineering Department, Petra Christian University, Surabaya, 2019 (In Indonesian).

12. Santoso, D. I. and Susanto, J., Efek Dinding Bata Pengisi Terhadap Kinerja Seismic Rumah Sederhana, Undergraduate Theses, Civil Engineering Department, Petra Christian University, Surabaya, 2020 (In Indonesian).

13. Computers \& Structures, Inc., CSI Analysis Reference Manual, Berkeley, California, USA, 2016.

14. Kadysiewski, S. and Mosalam, K. M., Modeling of Unreinforced Masonry Infill Walls Considering In-Plane and Out-Of-Plane, Pacific Earthquake Engineering Research Center, University of California, Berkeley, 2009.

15. SNI 2847-2013, Persyaratan Beton Struktural untuk Bangunan Gedung, Badan Standardisasi Nasional, 2013 (In Indonesian).

16. SNI 1726-2019, Tata Cara Perencanaan Ketahanan Gempa untuk Struktur Bangunan Gedung dan Non Gedung, Badan Standardisasi Nasional, 2013 (In Indonesian). 